\title{
Derek Mahon as Translator
}

\author{
R. A. York \\ University of Ulster
}

\begin{abstract}
Derek Mahon has devoted much of his productive life to translation, especially from the French. This paper studies his handling of French texts, distinguishing those which he has freely recreated from those which he has assimilated to his own style and those where he has made himself subservient to the character of the original author. Attention is drawn to his inventiveness, his wit, his moderation and rationality, his concern for effective and relevant communication with the reader, his rhythmic sense and his concern for emphasis and coherence. It is argued that the practice of translation affords Mahon the opportunity to write "at one remove" from direct feeling, and in so doing to combine breadth of feeling and of cultural reference with self-awareness and self-discipline.
\end{abstract}

Derek Mahon is one of the outstanding Northern Irish poets of the present day. He shares with many modern Irish writers, such as Seamus Heaney, Brien Friel and Tom Paulin, a strong interest in translation, a surprisingly strong interest perhaps for some non-Irish readers, who may not be fully aware of the Irish fascination with other cultures and with the challenge of assimilating or transposing works from other languages, other societies and other periods. Translations (or adaptations - the distinction is not always clear) account for a large part of Mahon's output: if we note translations from French alone we find that in the Poems 1962-78, there are the quite long versions of Villon's "Petit testament" (or "Lais") and Corbière's "Le poète contumace," as well as the versions of three poems by Jaccottet and the version (in fact an extremely brief condensation) of Guillevic's "Les Rocs." The Hunt by Night contains his handling of stanzas from Rimbaud's "Bateau ivre"; in separate volumes he has published his translations of Nerval's "Les Chimères," of Molière's École des maris and École des femmes, and what is perhaps his outstanding work as a translator, his bilingual edition of poems from Jaccottet (which incorporates a modified version of the Jaccottet poems included in an earlier volume). There are also several translations from other languages: Latin, German, Russian, modern Greek. Mahon, that is, must have spent a large proportion of his literary 
activity coming to terms with the lyric or dramatic imagination of other, foreign writers. This alone suggests an extraordinary modesty or discretion; he has often made himself the voice of other people rather than seek to assert his own conceptions and his own imagination.

This paper will seek to move towards an understanding of what is involved in this project, what exactly this modesty indicates about his creative sense. We shall see that his service to the authors he translates varies greatly, from a bold recreation to an almost impersonal transposition; but what we should note at this stage is that a preoccupation with the alien has been a distinctive feature of a great deal of Mahon's writing. He refers readily in his poems to works of culture as well as to direct experience, seeing the significance of the scenes or episodes he depicts often in terms of an accumulated cultural tradition, in which such figures as Brecht, Cavafy, Rilke, Camus, Chekhov, Basho and many other foreign writers (and also painters) play a large part, often seeming to act as personae, or masks, for the author. This may be viewed as a "fabricated cosmopolitanism," in Brown's term (196). But there is much more to it than that. His predilection for the foreign may be viewed in two ways; on one hand it expresses his discontent with what he sees as the provinciality and inflexibility of the culture of Northern Ireland, and the search to transcend home, class and history of which Dawe speaks (218); on the other hand, the figures through whom Mahon chooses to represent himself are often figures of exile, Romantic outsiders (Brown, 196), or displaced Modernists (Dawe,221): Villon bequeathing his largely non-existent property to his acquaintances as he abandons Paris for the provinces, Corbière's apparently Parisian poet living in the depths of Brittany (and becoming in Mahon's version a "poet in residence" - a title which Mahon himself has held, apparently without much pleasure, leaving Southern England for the bleak North of Ireland, a move on which he reflects also in "The Return"). If we seek to combine the two perspectives we have a view of an individual, rich in cultural awareness and open to many areas of knowledge and feeling, seeing a society from the outside, and being conscious both of the sense of community, of belonging and certainty, that is lost to the exile, and also of the freedom, the intellectual exploration, the sensitivity to a wider — and often more extreme or irrational - area of feeling than can be afforded by any one community. "I am trapped .../In my own idiom," he reflects in "The Sea in Winter" (P, 113); translation offers a contact with other idioms and so, possibly, an escape from entrapment.

This feeling of curiosity, this exploration of the other world of foreign cultures has been sensitively investigated by Catherine McCracken in her paper to the 1988 conference of the International Association for the Study of Anglo-Irish Literature. The present study seeks to add a detailed consideration of how, precisely, Mahon has responded to and transformed the language of the originals. It deals only with the works derived from the French, a language Mahon studied at University, which are his largest body of translations and which allow consistent comparison. In dealing with French verse, any translator has to cope with a number of essential linguistic and cultural differences; notably that French verse is based not on stress or length but on the number of syllables in a word group, and so involves different rhythmic patterns (and perhaps therefore different rhythms of feeling) from English verse, and that the tradition of French verse is dominated by a rhetoric of symmetry, order, abstraction and often conventional metaphor which attains a kind of 
dignity rather alien to the comparatively concrete and anecdotal manner which is more normal in English writing (and this is pertinent even to an extremely bare and restrained writer such as Jaccottet: his work is strikingly simple and austere, in French terms, precisely because he is restricting his use of the French tradition of eloquence, and even though eloquence is restricted in Jaccottet's poetry it is certainly not eliminated from it).

One's first comment on Mahon's treatment of French simply has to be on the accuracy of his grasp of the language. It is worth commenting on the few exceptions, simply because they may lead to confusion in the reader's mind, but the important thing is really that there are so few of them, and that some depend on quite subtle aspects of the language. The most frequently occurring mistake is that he appears to believe that the word franchir means something like "to liberate," as in a poem from Jaccottet, who is unfortunately particularly fond of the word, where we find "light that releases words/as if erasing them" for "une lumière qui franchit les mots/comme en les effaçant" (in fact "a light which traverses words") and "Quick, clear this space again with your hand" for "vite, franchis encore cette distance avec ta main" (actually "cross this distance") (J 122-3 and 126-7). In the poem "Paroles dans l'air" (J, 48), the word "sens" probably does not have the same meaning at the end of lines 10 and 12, as Mahon implies by using the word "direction" each time; it is much more likely that the first occurrence, in the phrase "avoir un sens," means "sense" or "meaning," while the second, in the context "avancer dans ce sens" probably does mean "direction." In the same volume, Mahon falls into a similar difficulty, this time no doubt caused by a subtlety of the French conventions of versification. In French verse, a word cannot rhyme with itself; "mon coeur feu," at the end of Corbière's "Poète contumace," must therefore mean "my late (i.e. dead) heart," since "feu" rhymes with "feu" in the next line, where it clearly means "fire"; Mahon mistakenly translates by "fire" both times. There are occasional misconstruals of Jaccottet's sometimes quite complex syntax: so in the poem "Dans l'herbe à l'hiver survivant" $(\mathrm{J}, 64)$ he appears to miss the construction, frequent in French verse but very rare in prose, by which a de complement precedes the phrase it qualifies. Jaccottet writes:

\author{
Dans l'herbe à l'hiver survivant \\ ces ombres moins pesantes qu'elle \\ des timides bois patients \\ sont la discrète la fidèle
}

l'encore imperceptible mort.

The shadows are the death of the woods, mentioned two lines before mort; Mahon fails to perceive this and produces a rather awkward, and certainly inaccurate version in which

These wood-shadows, timid, patient ... are the discreet, faithful,

barely perceptible shadows of death. 
Similarly in "Nuages de novembre" Jaccottet speaks of
d'invisibles bêtes
après d'autres, depuis toujours, qui sont venues, silencieuses, blanches, lentes, au couchant
(ayant été dès l'aube obéissante au soleil sur le grand pré)
laper cette lumière ...

Mahon, not surprisingly perhaps, appears not to recognise that "laper" is dependent on "sont venues" (thus meaning "came to lap"), and translates it as the beginning of a new sentence, "Absorb this light" (J, 138-9). It must be admitted that the conception of the person addressed absorbing light is a fine and effective one; but it does not match Jaccottet's thought and forces the translator to add an extra verb ("have drunk since time began") to explain the arrival of the animals, thus making Jaccottet's work somewhat less discreet and elegant.

There are some other mistakes, or apparent mistakes, in Mahon's work, and there are details - such as puns and verbal allusions - which he has found impossible to capture; an example is the poem "Figues et raisins" (J, 96), where he has found no way of capturing the reference to the French idiom mi-figue mi-raisin ("semi-humorous"). These limitations should not weaken seriously our respect for his readings; the rest of this paper will show how far they are not only reliable and accurate but deeply sensitive and sympathetic accounts of his originals.

But this fidelity to the texts is not mechanical or impersonal. Mahon is always, it seems, aware that translation means interpretation, that the translator must necessarily select what elements in the text are of primary value to him and to his readers, and that he must handle the text in such a way as to highlight these crucial elements. In the light of this principle, we can distinguish three major tendencies in Mahon's work as a translator: he can boldly recreate, producing a work which the original author might hardly have recognised (and such work may be clearly labelled as "after" or "based on" the original author); he can appropriate, making the text - by minor adjustments - into an utterance that is easily perceived as congruent with the persona apparent throughout the rest of Mahon's writing; and he can subordinate his own personality, discipline his own personality, to adopt a stance and form of utterance somewhat beyond his normal range - though it may be fascinatingly analogous with his normal writing, or an extrapolation from certain tendencies within it. Examples of the first manner are the Molière adaptations and the first version of Nerval's "Vers dorés" ("The Mute Phenomena," P, 69); in the second group we find his accounts of the Villon "lais," the Corbière poem and the "Bateau ivre"; in the third group there are the complete set of Nerval translations (The Chimeras) and the masterly volume of Jaccottet. If one can hasard a generalisation, it must be that the theatrical incites Mahon to recreation, and that apart from this, his tendency has been increasingly towards self-effacement in translation; it may be that as his own writing - and imagining have grown more disciplined, more austere, his sense of humility before the visions of other writers has grown stronger. 
The major feature of the recreative translations is their comic exuberance, their playfulness. The point is especially obvious in "The Mute Phenomena," which reads almost like a parody of the original, which itself is far from comic, and shows little concern for word-for-word loyalty to the original, or even for loyalty to its overall tone. The point is apparent in the first two lines. Nerval writes:

Homme, libre penseur! te crois-tu seul pensant

Dans ce monde où la vie éclate en toute chose?

Mahon offers:

Your great mistake is to disregard the satire

Bandied among the mute phenomena.

Gone is the rhetoric, the exclamation, the rhetorical question, the hyperbole of "toute chose," gone too the insistent and solemn regularity of rhythm; they are replaced by a firm directive, rather prosaic and chatty, introducing the completely new idea that the attitude of the natural world to humanity is one of satire and hinting that this idea itself is somewhat absurd by the use of the term "bandied," with its suggestion of irresponsible, gossipy malice. And yet there is a real seriousness within this fairly broad comedy, which is implied in the ingenious references back to the Nerval poem, appearing at just the moments when it appears to be totally forgotten, and in the gravity of some of the inventiveness. We note, for instance, the third line and its sequel. For Nerval's

Des forces que tu tiens ta liberté dispose

Mahon gives us

Be strong if you must, your brusque hegemony

Means fuck-all to the somnolent sunflower

Or the extinct volcano.

There is absurdity in the obscenity and in the over-precise specification, as sunflower and volcano, of what appears in Nerval only in the phrase "l'univers est absent"; it seems that Mahon is mocking the vagueness and pretentiousness of the French poet. But that third line is not so straightforward. It really does echo the symmetry of Nerval, balancing strength and liberty even if liberty is conceived in the twentieth century politicised and ironical framework of "hegemony"; and the coupling of "brusque" with "hegemony" adds a startling disquiet, very apt to a quite genuine criticism of human exploitation of nature. The last line, too, expresses a seriousness so far repressed or masked. For Nerval's 
Mahon provides an equivalent which is as strongly metrical, as prophetic, and even more abstract:

The ideal society which will replace our own.

There is absurd fantasy in the idea that our society will be replaced by a non-human one, as there is - after all - in the Romantic concept that there may be a God inside every stone (though admittedly the poet was to speak later of his "misgivings ... . About the true importance of/The merely human," $H, 63$ ); but the idea that our society needs to be replaced, that it is far from ideal, is one that appeals quite seriously to many readers, and suggests a political discontent that is the modern equivalent of the Romantic discontent with the artificiality of rational humanity.

Similarly the treatment of $L ' E ́$ cole des maris and L'École des femmes combines an apparent disregard for the author with a measure of respect for his major concerns. Mahon produces lively dramatic works, readily stageable, extremely funny, and perhaps all the more effective for the abridgement of many of the speeches, and especially of the longest ones (which are sometimes run together to ensure a rapid flow of action, as with Arnolphe's final soliloquy in Act III of The School for Wives and his opening speech in scene IV)). (Some rather secondary scenes are also omitted, and some minor roles combined, no doubt for reasons of dramatic pace.) At times Mahon is astonishingly accurate in reproducing the pace and dynamism of the original: one may cite, for instance, the elegant couplet in which Arnolphe states his ideal of womanhood: for Molière's

Et c'est assez pour elle, à vous en bien parler, De savoir prier Dieu, m'aimer, coudre et filer,

Mahon gives us

There's only four things I would have her do: love God and me, and learn to knit and sew.

Here Mahon nicely preserves the - perhaps complacent, over-confident - harmony and order of the verse. Elsewhere he forcefully captures the balance of broken exclamatory syntax and rhythm with the continuing presence of a regular meter in these lines from Act I sc iv of the École des femmes:

Et pourvu que l'honneur soit ... Que vois-je? Est-ce ... Oui.

Je me trompe ... Nenni. Si fait. Non, c'est lui-même, Hor...

Horace Seigneur Ar...

Arnolphe

Horace

Arnolphe
Horace.

Arnolphe.

Ah! joie extrème!

Et depuis quand ici? 
The naturalness and vivacity of this sets a severe task to the translator. Mahon succeeds remarkably:

\author{
her virtuous nature. .. Who's this? Is it ...? No, \\ it can't be ... Yes, it is ... Just like his dad ... \\ Horace! \\ Horace Monsieur Arnolphe! \\ Arnolphe \\ Come here, my lad, \\ till I embrace you.
}

(That "till," incidentally, is one of the few recognizably Irish idioms in Mahon's writing, though High Time, his version of L'École des maris, is more systematically Irish.) Overall the sense of good-humoured surprise is superbly captured. But some comments are called for, which show how far Mahon has modified the impact of Molière's plays. Firstly, the enjambement; perfectly appropriate here, it nevertheless recalls that enjambement is in fact much more frequent in Mahon than in Molière (or, indeed in most of his sources) and that the decorum and artifice of classical verse come much less naturally to him than to Molière. Secondly, the familiar “dad"; Mahon's play is much more colloquial than Molière's. In fact the colloquial tone, in both Molière translations, not infrequently encompasses the use of obscenities, unthinkable in French classical drama, and generally suggests a cruder, more immediate and violent sensibility than Molière indicates. So a line like "I ought to sock you for a crack like that" (against "Et quelques coups de poing satisferaient mon coeur") may suggest the comedy of Holywood rather than Versailles. More importantly, what is lost here is the tragic dimension of Arnolphe. Molière's character, like the Mahon equivalent, certainly is arrogant, bad-tempered, hasty, lacking in self-awareness; but Molière adds an extra dimension to him by making him echo the vocabulary of classical tragedy, as with "mon coeur" here, a whole line quoted from Corneille elsewhere (could Mahon have found some apt Shakespearean equivalent?) and a host of solemn and grandiose rhetorical phrases throughout the play. It is revealing that more than once, when Arnolphe speaks of "honneur," Mahon translates by "selfesteem"; the sense may be accurate enough, but the emotional connotations are quite different; honour is tragic. The point is a complex one; at times Molière seems to invite some sympathy for the sufferings Arnolphe brings upon himself; at times he seems to imply that tragedy as such is a matter of arrogant self-regard and so is justly parodied in his irreverent drama. The forceful vulgarity of Mahon's Arnolphe loses this point completely.

This is not the only modification in the plays. Very conspicuous, and very neatly done, are the transposition of the École des femmes from the seventeenth century to the early nineteenth, and its location in Avignon (the town being unnamed in Molière). The device involves some elegant surprises; the précieuses of Molière appear as Romantic feminists in Mahon, and there is an ingenious aptness in passages such as the one where Molière's "damoiseaux" with their "grands cheveux, belles dents, et des propos fort doux" are metamorphosed into 
young bucks with their curly hair

by Scaramouche; you see them everywhere, flashing their gnashers at salons, at Rick's...

There are even occasional hints of the 1970's: Arnolphe is against "reds and queers"; he addresses his servants as les misérables (the Hugo novel or the modern musical?), Chrysalde dismisses "that open-marriage crap." High Time is systematically modernised, so that Molière's "manches qu'à table on voit tâter les sauces" and "cotillons appelés hauts-de-chausses" become

... a shirt like a tequila sunrise, shorts

so long they trip him up on the squash-courts. (HT, 12)

This is all very witty; but it is, in a sense, wit at a distance, wit which amounts to a playing with the status of the original, a questioning of what is characteristically seventeenth century in it. Even more, there is a good deal of humour - and very effective humour at the expense of its Frenchness; the absurd rhymes of "Avignong" with "long"and similar words (a joke much repeated), of "hieu" ("here") with "Mon Dieu" of "behavieux" with " "mon vieux," Arnolphe's claim that, with firmer treatment of young men,

there'd be less parlez-vous in Avignong,

even the location of part of the action in the rue Molière: all this suggests that the whole business of taking over a play from a foreign culture is funny in itself. Similarly in High Time the name Val (Mahon's modernisation of the classical Valère) is made to rhyme with un scandale (56), and a particlarly brilliant conceit works only for people who recall the original very closely: the rhyme "abhor-adore" is used to represent the pair "abhorre-adore" in the original (22)! This self awareness is, certainly, typical of Mahon, and it is fascinating to see the lyrical, contemplative self-questioning of his original verse being transposed into a dramatic and absurd self-irony on stage.

But what is questioned here, the possibility of a real contact with the foreign culture, is precisely what is attained elsewhere. The first stage in attainment of it is in those works (Villon, Corbière, Rimbaud) where the translator is perceptibly present in his own character, but where this character appears not only as a "poète maudit," but also as a voice of moderation and efficiency. In these poems, first of all, there is a principle of economy which goes further than the dramatic economy of the Molière works; large parts of the originals are omitted, most strikingly perhaps in "The Drunken Boat," which is reduced from a hundred lines to forty-eight, losing many of its most picturesque and hallucinatory stanzas. What is true on the level of overall construction of the poems is also true of the detail of the text; in the translations, details are rarer, and perhaps more effective. So the weather information in Villon's "Lais" is much condensed. The original has

Sur le Noël, morte saison, 
Que les loups se vivent de vent

Et qu'on se tient en sa maison,

Pour le frimas, près du tison;

Mahon eliminates the specific reference to frost and fire, but strikingly hints at frost in a colour-epithet, thus reducing the four lines to two:

(Black-and-white January weather,

Wolves howling at night sometimes).

Similarly, for Corbière's rather loquacious evocation of his neighbours:

Nous avons des amis, sans fard, - Un braconnier;

Sans compter un caban bleu qui, par habitude,

Fait toujours les cent-pas et contient un douanier,

Mahon gives us simply,

Moreover, you need not feel solitude

What with the poacher and the exciseman. $(P, 105)$

The sense of economy is strong; the appeal of the speaker in Mahon is to the rational, business-like feelings of his hearer, not to any admiration for fantasy or charm, and so it excludes chatter. Economy, that is, means moderation; and this moderation of tone and personality is apparent throughout these adaptations. Thus Villon leaves to his unkind mistress

mon coeur enchassé,

Pâle, piteux, mort et transi...

Mahon replaces this fine self-pitying rhetoric with irony:

I leave my heart, an empty bag

For her to play with when it rains. (P, 21)

At the end of the Rimbaud poem we find this discreetly elegiac stanza:

Meuse of the cloud-canals, I would ask of you

Only the pond where, on a quiet evening,

An only child launches a toy canoe

As frail and pitiful as a moth in spring. $(\mathrm{H}, 54)$

This is the original text:

Si je désire une eau d'Europe, c'est la flâche 
Noire et froide où vers le crépuscule embaumé

Un enfant accroupi plein de tristesses, lâche

Un bateau frêle comme un papillon de mai.

The essential fidelity is remarkable; but so are the constraint and self-discipline, qualities rare in the young Rimbaud, but crucial to Mahon, in whose writing they constantly are set against expansiveness and commitment to the richness and variety of life, to the wonder of life.

In general this group of translations is remarkable for a rhythm that imposes a sense of delicate self-discipline; so towards the end of the Corbière version we find these lines:

\author{
You inhabit my dreams and my day-dreams; over \\ Everything, like a spirit, you hover. \\ You are my solitude, my owls \\ And my weathercock. $(P, 106)$
}

The Corbière text is this:

- Je rêvasse... et toujours c'est Toi. Sur toute chose,

Comme un esprit follet, ton souvenir se pose:

Ma solitude - Toi! - Mes hiboux à l'oeil d'or;

—Toi! Ma girouette folle: Oh Toi....

Mahon has reduced the epithets and the visual details; and he has created a powerful but regular and fairly even rhythm, as against the rhythm of Corbière, which dramatises the disturbed emotions of the speaker by its rapid alternation between the symmetrical balance of the second line quoted and the disruptive exclamations of the rest of the passage. Continuity of tone, it seems, is a matter of importance to Mahon; his persona is not allowed to yield to the surprises of his own emotions, not allowed to insist as Corbière's character does. On the contrary, he finds a sameness of effect within the rapid shifts of attention signalled by the jerky introduction of solitude, owls, weathercock. The translation, that is, can be seen as an act of mastery; given the harsh and disquieting raw material provided by the foreign poet - albeit a poet who already has a sense of irony like that which is so characteristic of his translator - Mahon's response is to impose order, to impose the perspective of a fixed, almost calm self-analysis. Edna Longley (170-184) has written forcefully of Mahon's mastery of sentence and stanza structures; such translations as this show how far this amounts to a mastery of selfhood.

Mahon, then, is regarding these texts as raw material, and wishes to control their rawness. This is no longer the case in the two full volumes of verse translation, from Nerval and from Jaccottet. In the case of Jaccottet, the reason may seem clear enough; Jaccottet is already a poet whose major quality is precisely his detachment from life, his melancholy sense of the emptiness and vulnerability that lie within experience, and who has masterfully discovered forms of verse which bring out the capacity of language for bare, grave formulations of the recognition of loss and absence (so that on occasion Mahon even makes his tone somewhat more vital, more engaged than that of the original). In the 
case of the very Romantic and rhetorical Nerval, the reasons are less easy to find. Certainly Nerval displays very clearly a concern with sound patterns and rhythmic effects of the kind which are frequent - if usually less conspicuous - in Mahon's original writing. The mythical and religious dimension may perhaps seem much less natural to Mahon; but there is at least in much of his work a haunting sense of the possibility of another life, of another, intuitive and irrational, way of responding to the texture of experience. He has a hunger, as Watson comments, for "places of the mind, beyond time, out of time" (221). And this hunger is perhaps a modern - and so very much attenuated - form of an aspiration to the transcendental. In Mahon it does not usually take the form of intensely emotional narrative, as it largely does in Nerval (and in mythic writing in the strict sense altogether); it appears, for instance, in the recognition, expressed in "The Woods," that

\author{
Another light \\ than ours convenes the mute \\ attention of these woods tonight - \\ while we, released \\ from that pale paradise \\ ponder the darkness in another place. $(\mathrm{H}, 58)$
}

Mahon's religious sensibility (if the word is not too strong) is an escape from paradise, an awareness of absence and limit. In this it clearly resembles the range of feelings in Jaccottet, and it is not excessive to see it as anticipated, however incongrously, in Nerval's awareness of the possibility of doubt, of the death of the gods, of the mysteriousness of life and the instability of the personality.

These two poets, then, offer a double challenge and a double fulfillment to Mahon; the challenge of a poetic form which extends his own usual range, whether towards even greater restraint and indirectness, with Jaccottet, or towards eloquence and theatricality, with Nerval, and the challenge of the expression of an elusive, intuitive search for significant experience.

Mahon has met the challenge, and in doing so has produced some of his finest verse. This has led to a particularly deep engagement with the original texts, and to a particularly searching exploration of poetic form - and more profoundly of the conveyance of feeling through language, in tone, rhythm and emphasis - which has left its mark on many aspects of the translations.

Firstly, one should note that, while the translations are in many cases extremely literal, they can at times be quite bold, in the sense that they aim not at word-for-word equivalence but at an equivalence of verbal gesture (as manifest on the level of a stanza or group of lines). Jaccottet's "Intérieur," for instance, starts with a set of six lines in which the speaker, hesitantly, cautiously, rather awkwardly, seeks to relate three topics: his own patient endeavour, the details of his room, and the uncanny animation and change of the outside world:

Il y a longtemps que je cherche à vivre ici, 
dans cette chambre que je fais semblant d'aimer, la table, les objets sans soucis, la fenêtre ouvrant au bout de chaque nuit d'autres verdures, et le coeur du merle bat dans le lierre sombre, partout des lueurs achèvent l'ombre vieille.

Mahon's version discreetly conveys the effort and the discontinuity within the imposed unity of vision:

I have been trying for a long time to live

here in this room I pretend to like

with its table, its thoughtless objects, its window wide to the dawn leaves.

A blackbird throbs in the ivy; light

everywhere polishes off the ancient dark. (J, 28-9)

The differences are striking; to "live," because of the enjambement, appears at first to be an effort in itself, before we find that it is a matter of living in this room; the "this," more closely attached to the "here," suggests an ostensive precision of location; the "table," "objects" and "window" are features of the "room," i.e. are part of a normal order of whole and part rather than slipped into a list which has no very clear grammatical (and therefore logical) function; the window, in a quite common-sense way, is "wide to the leaves" rather than "opening the leaves," and the phrase is given a line to itself and further integrated by the alliteration "window wide," reducing the almost miraculous surprise produced by this opening to another realm of existence. The blackbird, which is the object of a new perception, opens a new sentence, in a dense and suggestive image ("the blackbird throbs"), which calls for concentration and wonder on the part of the reader, whilst the final line of the stanza fascinates because it combines the almost too colloquial "polishes off" (disquietingly colloquial, not just because of the suggestion of frivolous murder but also because of the disproportionate suggestion of a different domestic - kind of light) with the grave "ancient dark," with its suggestions of classical literature. In short, Mahon has concentrated his poetic effects into a crescendo (a favourite form in his original writing, as Longley comments), passing from two and a half more or less prosaic lines through the "thoughtless objects" to the "ancient dark," and has clearly marked off the last two lines - those dealing with the outside - as articulating the most imaginative and exalting experience, whereas Jaccottet has maintained a greater continuity of tone and verbal structure at the cost of a certain strain, apparent only if the reader finds himself asking what the grammatical function of "la table" is and how the "et" comes to link a sentence about the speaker's long-term mode of life with what appears to be a description of a lyric moment. Clearly the sensibilities of the speakers in Jaccottet's poem and in Mahon's translation are somewhat different; but they are fundamentally alike. Both are people who have difficulty in finding coherence in experience, between the self and the physical world, between the domestic realm and the natural world, between observation and imagination, and both poems demonstrate gestures of gradually imposed 
consistency, gradually discovered access to the other, gestures enacted in sound, grammar and rhythm as well as in the implied emotional stance of the speakers.

Such a sense of symbiosis is manifest throughout these mature translations of Mahon, and serves to place them amongst his major works, and among the most successful translations of literary history. Mahon's own characteristic voice is not wholly suppressed; but we can see it here as essentially devoted to service to his originals, as a dignified assertion of his being secondary to his foreign originals.

Take, for instance, Mahon's economy. We have seen in his previous works that Mahon tends to abridge, more or less radically, and to make his texts sparer and lighter than his models. The tendency reaches particularly subtle levels in the later works. An example appears in Jaccottet's "Les eaux et les forêts," which neatly brings out the balance of effect produced by economy. Jaccottet writes:

On voit scintiller des fumées

qui emportent ce qu'on brûla d'une journée.

This is Mahon's version:

and sparkling smoke carries away

whatever it was that was burnt today. (J, 30-31)

"Sparkling smoke" condenses the main clause of the Jaccottet line; it adds a striking alliteration, and the proximity of the terms heightens the paradox of the bright smoke, reminding the reader of a strange phenomenon, characteristic of the clear light of spring. But the total effect is more complicated; for the isolation of the "sparkling smoke" in a single distinctive phrase leads the translator to turn the image of the carrying away of the remains of the day into the main clause of the sentence, which appears, now, to be strangely relaxed and lengthy, with a large number of words of little precise visual or emotional suggestion; the economy of the opening phrase seems to have given way to a rather fumbling attempt at pedantic accuracy, actually losing the brilliant concision permitted by French grammar in "ce qu'on brûla d'une journée," "that part of a day which one burnt." This means that the Mahon version could be judged in one sense to be less economical than the original, since it occupies two full lines, whereas the Jaccottet is a line and three-quarters. In fact, this is where the difference between the two poetic traditions is relevant; Jaccottet gives one and three-quarter lines of French verse moving at a solemnly measured pace (essentially Alexandrines, though with some irregularities). Mahon gives us two lines of a much more rapid English four-stress meter (again with irregularities). Overall we have a characteristic difference of the rate of emotional development; in Mahon concentration of vision, rapidly moving away to serious, if clumsy, explanation of context and meaning; in Jaccottet a more thoughtful progression from a carefully formulated observation to a meticulous and harmonious statement of significance. The difference is an essential part of the process of transposition: what is enacted is a rhythm of discovery, of interpretation, with its surprises and its hesitations. In Jaccottet, the major discovery is obviously in the formulation of "ce qu'on brûla," 
whereas in the translation the trouvaille is the sparkling smoke; but in either case the balance of discovery and searching is there, and the displacement is itself a sign of the struggle to discover and formulate.

Such displacement can affect the total import of a passage. Nerval's "Antéros," for instance, ends with the threat of a dangerous new birth:

Et, protégeant tout seul ma mère Amalécyte, Je ressème à ses pieds les dents du vieux dragon.

Mahon, attaining a similar firm triumphant tone, stresses not the future but the past:

Now,

Sole tutelary, the dragon-teeth I sow

Before my expropriated mother's feet. $(\mathrm{C}, 12)$

"Sole tutelary" is a superbly elegant equivalent for "protégeant tout seul." Elegance is not wholly out of place in Nerval, even if this poem is less concerned with delicacy and suggestiveness that other of his works; but one should note that the elegance lies not so much in Mahon's words as in the fact that they represent a less remarkable original. The translator immediately restores the balance of neatness and fidelity, going on directly to capture the solemn rhetoric of the original with the "dragon-teeth" (which is conveyed especially by the mythical force of the presupposing article and by the archaic inversion of object and verb) but then has to find his way back to the origins of his text with the "expropriated mother," so that the poem appears as an act of homage, of loyalty to her, rather than as, finally, a threat to the "conquering god" of the fourth line. What Mahon shares with Nerval, it may seem, is a contemplative sensibility; the promise of action is alien to him and has to be muted.

Mahon appears to seek to combine a certain modesty and ordinariness with fidelity to his originals; in Jaccottet this may be justified quite readily in view of the original poet's self-effacingness; in Nerval, very much part of the French tradition of grandiloquence and of the Romantic manner of allusion and haunting incompleteness, there are more problems. In the beautiful, rather Goethe-an "Delfica," for instance, the second quatrain begins:

Reconnais-tu le TEMPLE au péristyle immense, Et les citrons amers où s'imprimaient tes dents?

The "Reconnais-tu" is parallel to the opening words of the whole poem, "La connais-tu," creating a sense of symmetry that one is tempted to call architectural; the definite articles, the capitals for "TEMPLE," the imperfect tense of "s'imprimaient," indicating a slip into momentary description, all suggest a private realm, shared only between the poet and the person to whom he speaks, but given dignity — one might say a public dignity — by the even pace of the Alexandrines, the technical vocabulary of architecture, and a subtle play of sound-echoes ("péristyle" - "citrons," "Temple" - "dents," to mention only two). 
Mahon, having used "do you recall" in the first quatrain, begins the second directly by naming more things which are to be recalled:

The temple with the enormous colonnade,

The lemons harsh upon the tongue - remember? $-(\mathrm{C}, 13)$

The first line appears to take literalness to the point of banality. "Enormous" is trivially colloquial in modern English, and the word produces an oddly limping rhythm. But the sound pattern here may - just - alert the attentive reader to an underlying cohesion, since "enormous," the very word which seems to render the line unpoetic, actually maintains a poetic density of sound, since it repeats the " $\mathrm{m}$ " of "temple" and anticipates the " $n$ " of "colonnade," which, moreover, proves also to contain the "l" of "temple"; these sounds are repeated yet again in the next line, harshly interrupted by "harsh upon the tongue" (as the poem suddenly slips into appeal to a new sense, that of taste, and does so in a particularly disturbing way). The parenthetic "remember" again looks oddly casual; invoking intimacy, Mahon - unlike Nerval - conceives of it in terms of informality. But once again the balance is restored. For Nerval's next lines,

Et la grotte fatale aux hôtes imprudents, Où du dragon vaincu dort l'antique senmence? . . .

he gives us

And that dark chasm, death to the hasty, where

The cold seed of the slain dragon is laid?

The play of sound and rhythm, the directness of threat ("death to the hasty"), the gothic visual sense ("that dark chasm"): all have become positively conspicuous. From the excessive modesty and relaxation of the previous lines, we have gone to an excess of apprehensive grandeur. Once again, that is, Mahon differs from his original by a clearer articulation, distinguishing private from mythical in a way rather alien to Nerval, who appears to have regarded his own life precisely as a myth. Mahon, that is, as translator, has made more explicit what is conveyed in his original through hints and assumptions. The procedure may perhaps be regretted; the attraction of Nerval may be thought to lie precisely in the extent to which he relies upon tone and verbal quality to convey attitudes such as the familiarity displayed in his lines 5-6 or the grave and anxious wonder of his lines 7-8, in the extent, that is, to which he maintains an appearance of private - or even hermetic - communication. But the intrusion of a translator is, ipso facto, a disruption of such privacy. The reader knows - from the moment he sees the title-page of the volume, where the translator's name is more prominent than that of the original author - that he is not hearing the immediate voice of the poet, that his experience in reading will not be a direct perception of the poet's obsessions as they appear in rhythm and sound (and even in imagery, although that is less affected by the process of translation) but a registering of the translator's reproduction of $h i s$ experience of the sensuous significance of the original. 
The translator must, that is, rationalise; he must explain, select, moderate, explicitate, because those are the things involved in the humble and solemn service of translating, of offering his readers access to an author more important than himself.

He explains by such things as the heightened articulation we have seen in "Delfica" and in many other poems. He explains too by such things as his replacement of the "bords infinis" in Jaccottet's "La nuit est une grande cité" by "the edge of a dream" (J, 20-21) or the clarification of tenuously imaginative lines by a more analytic equivalent, as in Jacottet's "Le locataire," where for the opening two lines,

Nous habitons une maison légère haut dans les airs, le vent et la lumière la cloisonnent en se croisant,

he gives:

We live in an airy house in the cloud kingdom

with wind and sun instead of ceilings and floors. (J, 50-51)

He selects, omitting details which may be strange to a modern English-speaking reader and so demand disproportionate attention, as with the Amalekite mother in "Anterros," with Cupid, Phoebus, Lusignan and Biron in "El Desdichado" (where, however, Byron — not Biron - is confusingly evoked by the spelling "childe," C, 9), or with Jaccottet's reference to the Parisian suburb of Robinson (J, 38-9).

He moderates the character of the speaker, making him, in general, less aggressive, less bold, less eccentric, less egoistic. Thus Nerval's Christ is dramatic, challenging:

Ils dormaient. "Mes frères, savez-vous la nouvelle?

J'ai touché de mon front à la voûte éternelle....

The news is of course, in one sense, the gospel; in another sense, it is a piece of boasting, which Mahon's Christ, with Anglo-Saxon modesty, replaces by a polite request and a respectful contemplation of the heavens, made perhaps the more surprising and noteworthy by the enjambement:

They slept. "Brothers, listen to me, my brow

Has touched the great vault of eternity.... $(C, 15)$

And even Jaccottet can at times be somewhat too outspoken for the discreet voice of his translator, as here:

All gentleness, of the air

or of love, is harsh on the other side:

fine Sun

days have their price, like parties

that leave wine-stains on the table at daybreak. (J, 31) 
There is here a beautiful balance of enjoyment and melancholy (the last two lines here curiously correcting the more disorderly party-going of the young Mahon in "The poets lie where they fell," P, 29). But this balance is less precarious than the balance of the original, as we realise when we note that "gentleness" stands for "douceur" (which should mean "pleasure, seductiveness" as well as "mildness"), "harsh" stands for "cruauté," and "price" for "rançon," while the "daybreak" is described in French as the time when "le jour nous inquiète." This hardly amounts to coarse hyperbole in Jaccottet; but it does mean that the French poet risks extremes that his translator avoids. And perhaps a translator should avoid extremes; perhaps the status of a translator as a representative, as a spokesman for the poet, as a mediator, quite rightly requires him to be modest, to avoid drama and intensity of feeling.

$\mathrm{He}$ explicitates in, for instance, treating the "ivresse" of Myrtho as "the light/Of secret lore" $(\mathrm{C}, 10)$, and "ces dieux que tu pleures toujours" in "Delfica" as "the archaic gods you mourn," and in the same poem by making it clear that it is "the Arch of Constantine" which is unmoved in the last line (since it is the same thing as the "Sévère Portique" (which is mentioned by Nerval but omitted by Mahon)) (C, 13). He explicitates again when he translates Jaccottet's

parce que tu seras peut-être ma patrie

by this:

since you may prove the familiar land I seek (J, 22-23)

or when he treats Jacottet's comparison of playing cards to "les papillons écoulés poussiéreux" in terms of "the powdery wings of fallen moths" (J, 36-7). The seeking, the wings are needed to make sense of Jaccottet: Jaccottet, like many modern poets, and especially, perhaps, many modern French poets, wants his reader to provide some of what is needed for comprehension; Mahon the translator, more considerate, more courteous towards the reader, eases him into contact with the foreign imagination.

Mahon, in short, rationalises; although modern poetry is often thought to be hostile to the rational, he nevertheless prizes clarity, orderly pace, decorum and comprehensibility. These are the values of civilisation, of an urbane shared culture, of Augustanism, as McGuinness argues, rather than those of the Romantic imagination. And yet Mahon shows how compatible they are with two kinds of Romanticism; how Nerval's concern for rhetoric can be transmuted into a concern to explain oneself, and how Jaccottet's exploration of negativity can be transmuted into a Stoic self-restraint in discourse and communication.

Kennelly, better than anyone else, has characterised Mahon's voice; he describes it as one of "calm and dignified balance, quiet, not too dramatic, consciously educated, learned but not pedantic, self aware and self mocking," "the kind of voice that craves an eloquent linguistic precision and often finds it" (148). He acutely sees that the logic of such a style is to "remove the self from the centre of the poem," and that this is why Mahon is so concerned with using other poets (so Kennelly considered Mahon's best 
poem, at the time of writing, to be "The Poet in residence"). What this paper hopes to have shown is that his transmutations of the strange into the disciplined are hard won, and that the effort they involve is precisely the point of them. A slight strangeness hangs over Mahon's translations; natural as his English idiom normally seems, in context certain details often don't quite convince, shifting a little oddly from colloquial to formal, from dense to wordy, from monologue to conversation. Always there is the sense of an "elsewhere," of the text from which Mahon's own text is derived, which must arouse the reader's curiosity, but which can somehow not quite satisfy it. Usually the text is not immediately available; we watch a play or read a volume of verse wondering what the original might be like (or perhaps trying to remember what it is like); we are aware of the limits of our experience, of its second-hand quality. And even when the text is actually printed in the same volume, as with the Jaccottet book, the original will be at least slightly more opaque to most readers, and the awareness of the changes Mahon has made, of the fact that he has not conveyed exactly the sense of the original, will be all the more acute. This seems to be pointing towards something rather paradoxical: that in Mahon the rational is a sign of a sort of mysticism; more precisely that the virtues of clear and responsible communication, which Mahon practices as a translator just as he does in his own writing, serve to draw attention to what is mysterious in speech, to what is characteristic of the verbal expression of a unique sensibility, the sensibility of a Corbière, a Rimbaud, a Nerval - at the broadest the sensibility permitted by the French language - and so to what cannot be conveyed by even the most respectful and talented translator. Mahon, in other words, writes at a distance from sensibility. Both the distance and the sensibility are essential to him, and the tension between them is a major factor in his poetic creativity. He says as much himself and, perhaps - ironically - depicts his own activity as translator in particular through the figure of van Meegeren in his poem "The Forger" $(P, 15)$ :

For even at one remove

The thing I meant was love.

\section{Works Cited}

Brown, Terence. Northern Voices. Dublin: Gill and Macmillan, 1975

Dawe, Gerald. "Icon and Lares: Derek Mahon and Michael Longley." Across a Roaring Hill. Ed.

G. Dawe and E. Longley. Belfast: Blackstaff, 1985. 218-235.

Jaccottet, Philippe. Selected Poems. Ed. D. Mahon. London: Penguin, 1988 (indicated in text as J). Kennelly, B. "Derek Mahon's humane perspective." Tradition and Influence in Anglo-Irish

Poetry. Ed. T. Brown and N. Grene. Basingstoke: Macmillan, 1989. 143-153.

Longley, Edna. Poetry in the Wars. Newcastle upon Tyne: Bloodaxe, 1986

Mahon, Derek. Antarctica. Dublin: Gallery, 1985. . The Chimeras. Dublin: Gallery, 1982 (C).

. High Time. Dublin: Gallery, 1985 (HT).

The Hunt by Night. Oxford: Oxford U. P., $1982(\mathrm{H})$.

. Poems 1962-78. Oxford: Oxford U. P., 1979 (P). 
McGuinness, A. E. "Cast a Wary Eye: Derek Mahon's Classical Perspective." Yearbook of English Studies (1987): 128-142.

Watson, George. "The Narrow Ground." Irish Writers and Society at Large, Ed. M. Sekine. Colin Smythe and Barnes and Noble, 1985. 207-224. 